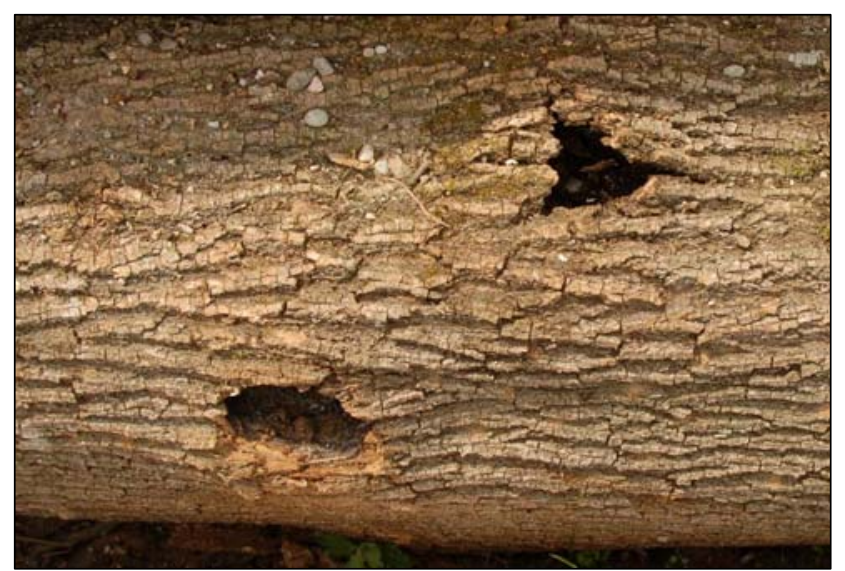

Slika 1: Jesenov glivični rak na velikem jesenu, rahlo privzdignjena skorja, skorja je razpokana $\mathrm{z}$ odprtino na sredini

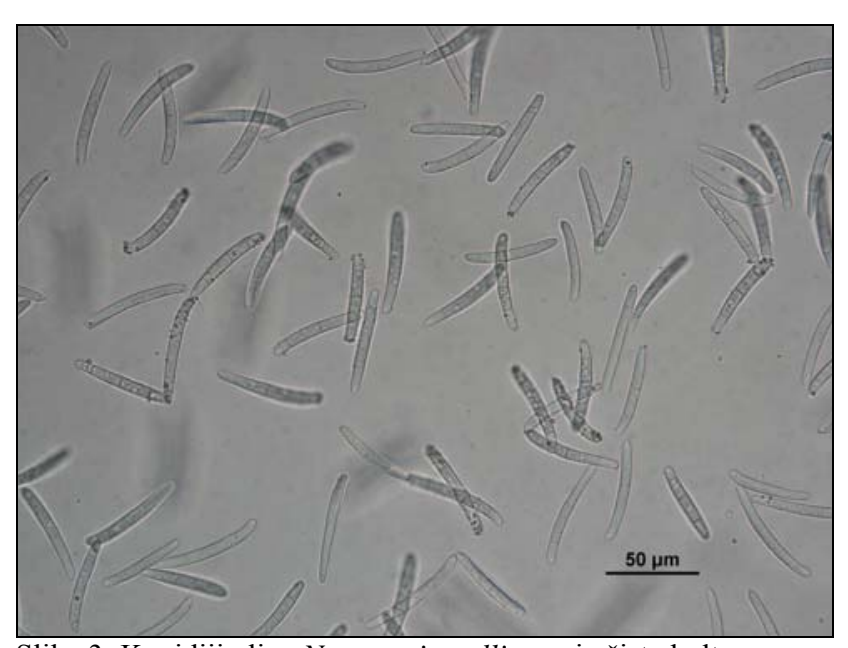

Slika 3: Konidiji glive Neonectria galligena iz čiste kulture

3: Konidiji glive Neonectria galligena iz čiste kulture

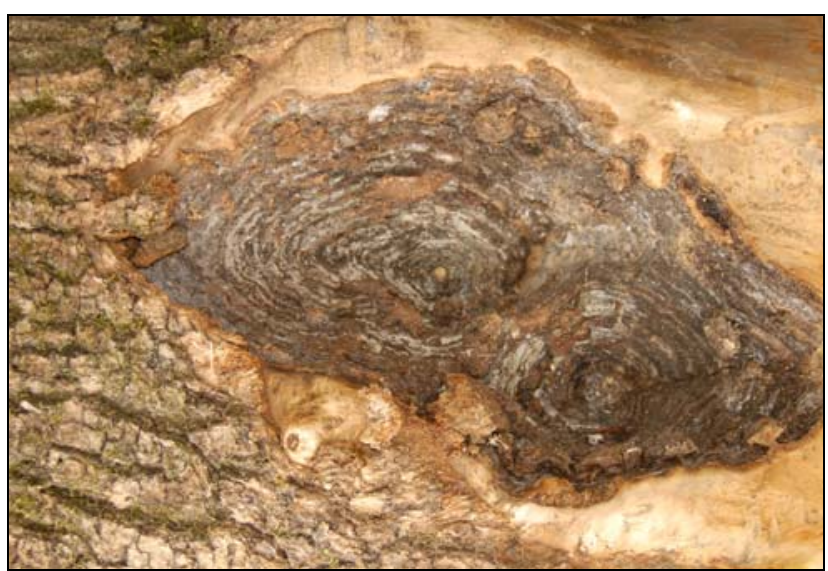

Slika 2: Pod skorjo je rak skoraj pravilne simetrične oblike

\title{
Posledice toče na gozdnem in okrasnem drevju v okolici Ptuja zaradi neurja avgusta 2008
}

\section{Nenad ZAGORAC}

Nevihta z močnim vetrom in zelo debelo točo (tudi velikosti kokošjega jajca) je v večernih urah 15 . avgusta 2008 zajela področje od mesta Ptuja preko Destrnika do Trnovske vasi v širini 5-10 km. Debela toča je poškodovala gozdove na površini okrog 2000 ha. Na gozdnem drevju je bilo po ocenah krajevnih gozdarjev poškodovanih 20 do $100 \%$ listja in iglic, tako da so določeni gozdovi bili videti kot jeseni (slika 1). Zanimiv je bil pojav na hrastih, ki so v septembru 2008 ponovno olistali in so bili zeleni v november do prvega mraza.

Posledice nastale škode so dobro vidne šele v letošnjem letu. V gozdovih so najmočneje prizadeta drevesa rdečega bora, ki marsikje niso ali ne bodo preživela, saj je bilo uničenih preveč iglic(slika 2). Močno poškodovana so okrasna drevesa zunaj gozda, ki niso imela zaščite sosednjih dreves (slika 3).Posledice na listavcih bodo vidne šele $\mathrm{v}$ naslednjih letih, saj poškodbe na poganjkih bistveno povečujejo možnost za razvoj bolezni in napada škodljivcev (slika 4).

Zavod za gozdove Slovenije, Območna enota Maribor, Tyrševa 15, 2000 Maribor

*nenad.zagorac@zgs.gov.si 


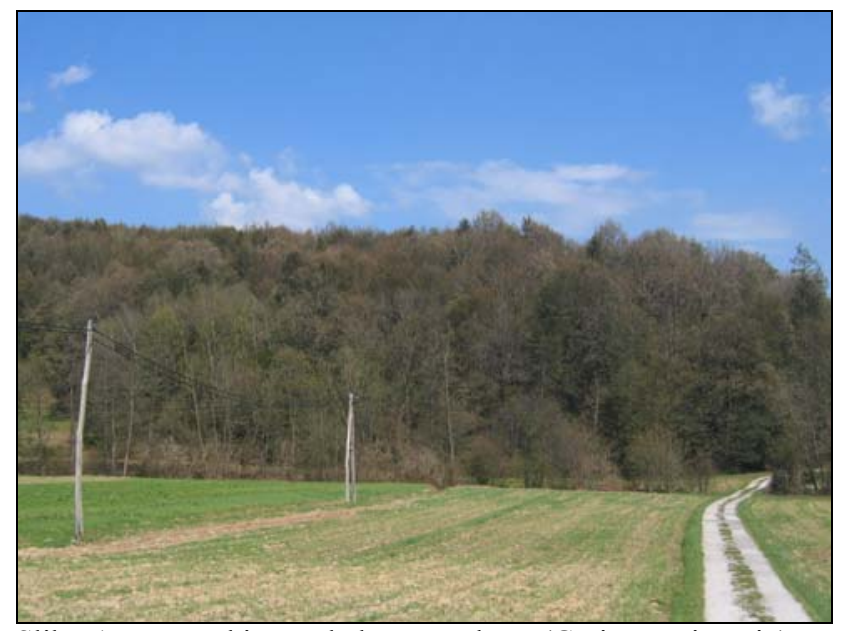

Slika 1: »Jesenski« pogled na gozdove (Grajena pri Ptuju) po neurju - foto avgust 2008

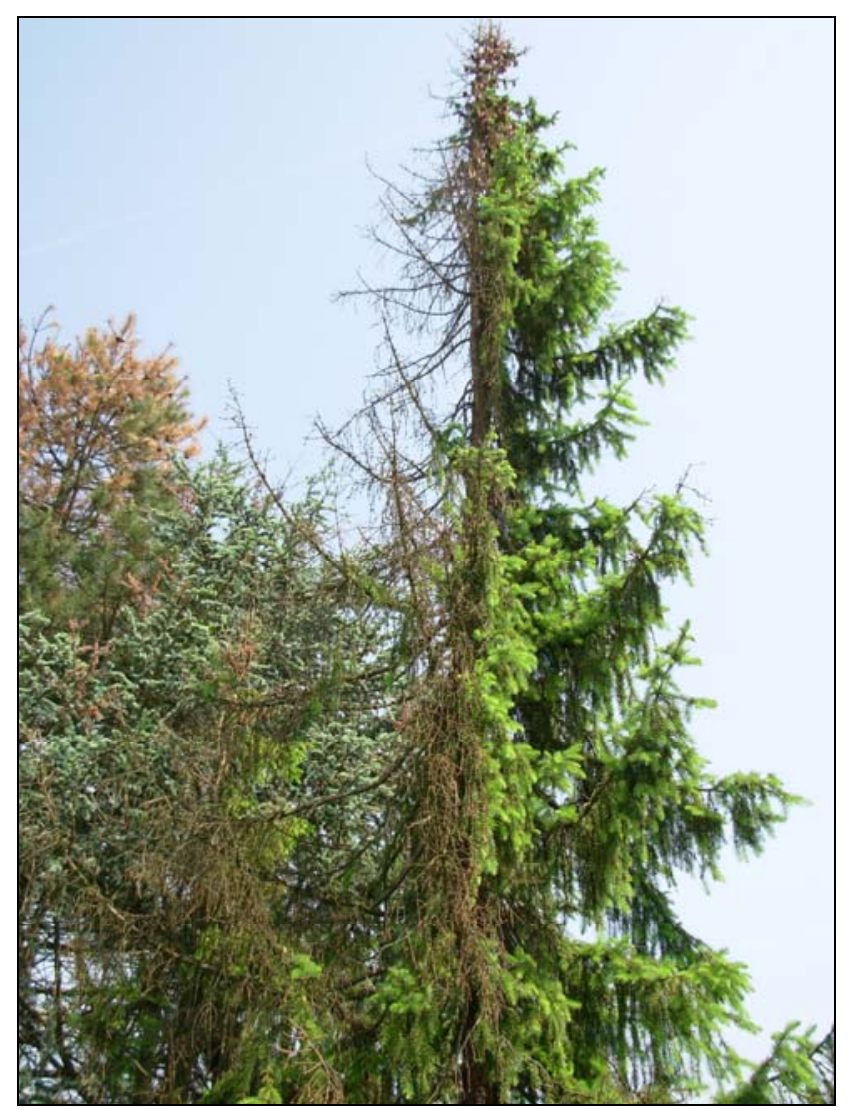

Slika 3: Poškodbe na drevju zunaj gozda (Grajena pri Ptuju) foto maj 2009

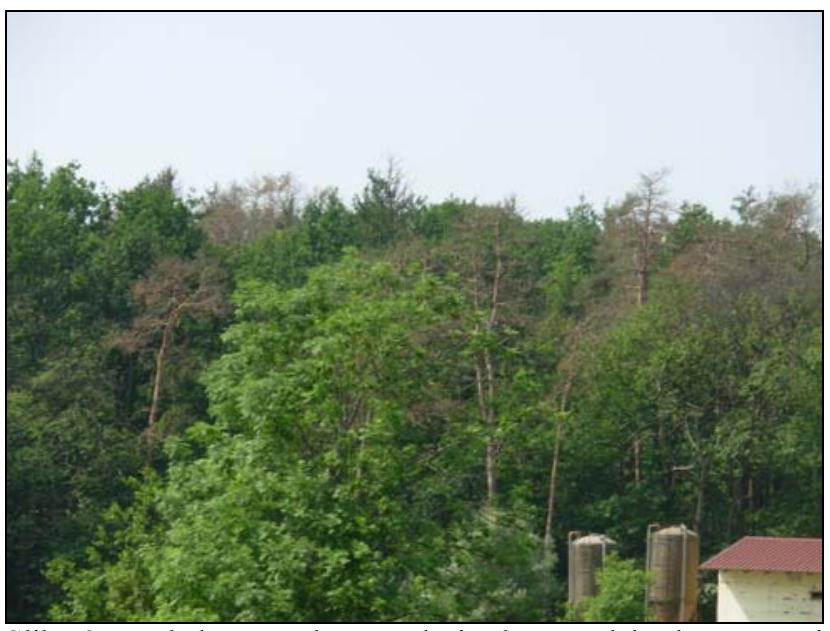

Slika 2: Pogled na gozdove $\mathrm{z}$ rdečim borom slabo leto po toči (Grajena pri Ptuju) - foto maj 2009

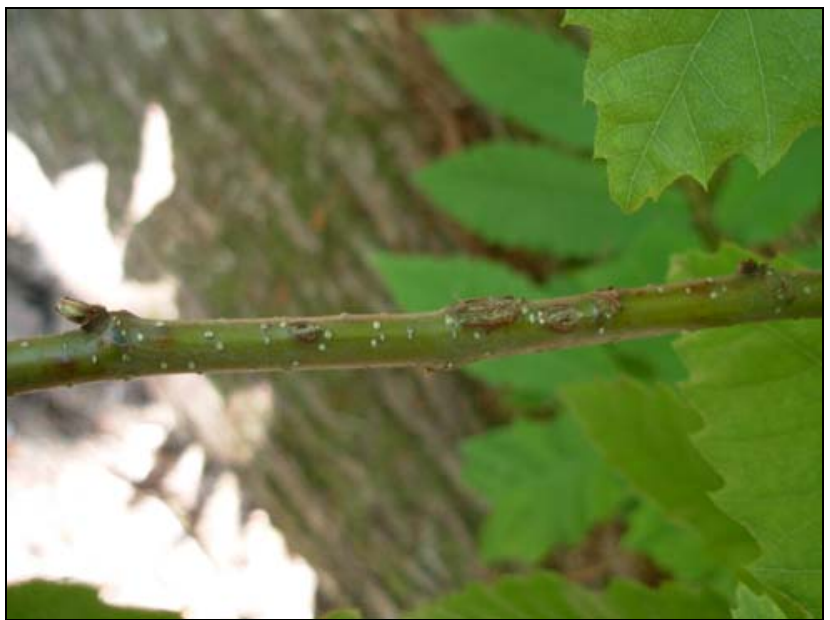

Slika 4: Poškodbe na kostanjevem poganjku - foto maj 2009

\section{Posledice snegoloma decembra 2008 v Gozdnogospodarskem območju Bled}

\section{Vida PAPLER-LAMPE*, Marija KOLŠEK}

Težak in obilen sneg je $\mathrm{v}$ drugi polovici decembra 2008 v Gozdnogospodarskem območju Bled poškodoval 49.000 bto $\mathrm{m}^{3}$ lesne mase na okoli 5.000 ha gozdov. Težišče snegoloma je bilo $\mathrm{v}$ nadmorskih višinah $1.000-1.300 \mathrm{~m}$ na planotah Pokljuke in Mežaklje.
Ogromne količine mokrega snega, ki je padal od 1. do 20. decembra 2008, so povzročile posamične in šopaste poškodbe pretežno čistih smrekovih sestojev v razvojni fazi drogovnjaka in debeljaka. Tipi poškodb so bili prelomi, cepljenja debel, podrtice posamičnih 